\title{
女性における腹部に意識を向けた呼吸活動について
}

\author{
$\bigcirc$ 井上彰子 $^{1} \cdot$ 田中仁秀 ${ }^{1} \cdot$ 小室央允 $^{2}$ \\ ( 1 駒澤大学大学院人文科学研究科 $\cdot{ }^{2}$ 駒澤大学文学部) \\ キーワード: 腹式呼吸, 呼吸活動, 女性
}

\author{
Respiratory activity during attention to abdomen for breath by moving it in a female \\ Akiko INOUE ${ }^{1}$, Masahide TANAKA ${ }^{1}$ and Hisayoshi KOMURO ${ }^{2,}$ \\ ( ${ }^{1}$ Graduate School of Arts and Sciences, KOMAZAWA University., ${ }^{2}$ Faculty of Letters, KOMAZAWA University) \\ Key words: Abdominal breathing, Respiratory activity, Female
}

呼吸には，胸部による胸式呼吸と腹部による腹式呼吸とが あり，女性は胸式呼吸が優位とされている。それは，妊娠と いう身体機能に対し，胸式呼吸は影響がなく都合が良いとい う生理学的理由によるところが大きい。

しかし, 腹式呼吸によるストレスの緩和やリラクセーショ ンの促進が注目されており，女性が腹式呼吸を行うことの効 果が期待されている。実際に, 柳・小池・小板橋(2003)の研 究において, 女性が腹式呼吸を行うことにより, 脈拍数の低 下と $\alpha$ 波含有率の増加が生じ, リラクセーションの効果を得 られるという可能性が示唆されている。

しかし，これまでの研究の多くは，呼吸法の即時的な側面 のみに着目しており，長期的な側面の検討は少ない。また， 呼吸法としての腹式呼吸を獲得するには，長期的な訓練が必 要であると考えられる。

そこで本実験では，胸式呼吸が優位とされる女性に対して 腹式呼吸習得のための腹部に意識を向けた呼吸の訓練を行う ことによって，呼吸活動にどのような変化がみられるのかを 検討した。

\section{方 法}

本実験では，呼吸活動の分析として，分時換気量(VE), 一 回換気量 (TVE), 呼吸数 (RR), 酸素消費量 $\left(\mathrm{VO}_{2}\right)$, 二酸 化炭素産出量 $\left(\mathrm{VCO}_{2}\right)$, 吸気時間 $(\mathrm{Ti})$, 呼気時間 $(\mathrm{Te})$, 呼 吸時間 (Ttot), 吸気時間率 (Ti/Ttot) を指標として測定した。 また, 胸部(rib)・腹部(abd)それぞれの呼吸曲線も記録した。 実験参加者 : 健常女性 1 名（24 歳）

記録装置: 呼気ガス分析は, ミナト医科学株式会社製 AE-300S によって行なった。測定值の記録及び解析は, 分析器に連動 された Dell Latitude AEC-3000を用いた。胸部・腹部の呼吸曲 線は, RESPITRACAE (Ambulatory Monitoring, Inc) により記 録した。

手続き：胸部と腹部にコイル付きのバンドを巻き, トランデ ユーサー付きの呼吸マスクを装着した。その後, まず安静状 態 (rest) として 15 分間測定し，5 分間の休憩を挿み，腹部 に意識を向けた呼吸条件（exercise）を15 分間測定した（セ ッション 1)。一週間毎に同様の手続きによる測定を計 7 回試 行した。

\section{結 果}

各セッションでの安静時および訓練時における, 胸部と腹 部それぞれの換気量を図 1 に示した。図 1 にあるように, 安 静時では, 胸部による呼吸が優位であったが, 訓練時では腹 部による呼吸が優位となった。

VE は, 全セッションにおいて安静時よりも訓練時で減少し た。安静時は全セッションを通してほぼ一定の值であったが, 訓練時ではセッション 1〜3 にかけて徐々に減少する傾向を 示したのち安定した。TVEでは, 全セッションを通して訓練
時に安静時の 2 倍前後の増加を示した。また, 安静時は全セ ッションを通して安定していたのに対して，訓練時にはセッ ションごとに異なる不安定な変動であった。RR は，安静時 では全セッションを通して 20 回前後であったが, 訓練時では 10 回未満に減少した。 $\mathrm{VO}_{2}$ では, 全セッションを通して条件 間での差がほとんどなく安定していた。 $\mathrm{VCO}_{2}$ では，セッシ ヨン 1 において安静時よりも訓練時で増加したが, セッショ ン 2 以降では $\mathrm{VO}_{2}$ と同様に差がほとんどなく安定した。 $\mathrm{Ti}$ と Te は, 全セッションを通して安静時よりも訓練時に延長し, 安静時と訓練時ともに Tiよりも Te の方が長かった。安静時 は安定していたが, 訓練時ではセッションごとに異なった変 化を示し, 特にセッション 3 で大きな延長がみられた。また, 安静時の T tot に対して, 訓練時の Te はそれだけで安静時の Ttotよりも長くなっており, 訓練時の Ti は安静時の Ttot と同 程度の長さであった。Ti/Ttot は, 安静時よりも訓練時にわず かに増加した。

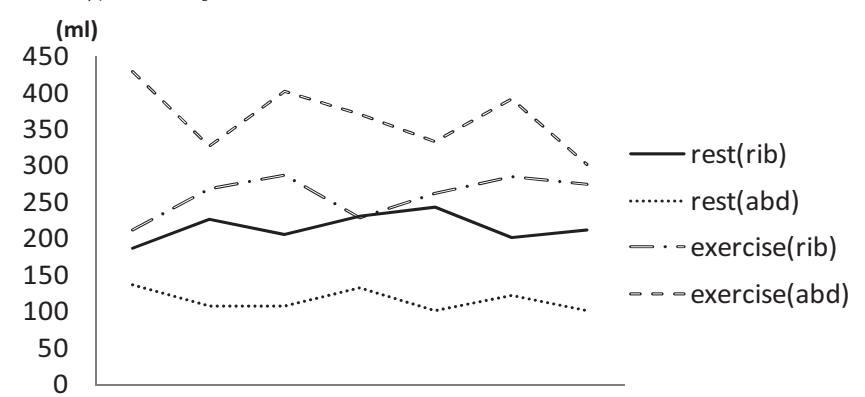

1st 2nd 3th 4th 5th 6th 7th session

図 1 各セッションにおける胸部と腹部の換気量の推移

\section{考 察}

腹部に意識を向けた呼吸を行うことによって，腹部優位の 呼吸一と変わり，ゆっくりとした深い呼吸が行われているこ とがわかった。この呼吸の変化はセッション 1 からみられ, 女性が即時的に意識的な腹部優位の呼吸を行うこと自体は容 易であったと思われる。しかしながら，腹部の運動はセッシ ヨンごとに大きさが異なり一定の傾向を示さなかったことか ら，長期的には試行錯誤を行っていたと思われる。また，呼 気ガスの観点からセッション開始当初は負担を伴う呼吸を行 っていたが，セッションを重ねるにつれて呼吸の負担は軽減 し安定していった。つまり, 腹部優位の呼吸では, ただ腹部 の運動を大きくすることよりも，試行錯誤を通じて自分にあ った腹部優位の呼吸をみつけるために, そしてその呼吸を定 着させるために長期的な訓練が重要であると思われる。今後, 更に長期的な訓練を行なうことで，より安定した傾向がみら れ，女性が自分に適した腹式呼吸を行えるようになると考え られる。

(Akiko INOUE, Masahide TANAKA, Hisayoshi KOMURO) 